\title{
Relational technologies as instruments of care in the Family Health Strategy
}

\author{
Tecnologias relacionais como instrumentos para o cuidado na Estratégia Saúde da Família
}

Tecnologías relacionales como instrumentos para la atención en la Estrategia Salud de la Familia

\author{
Tatiana Fernandes Kerches de Abreu', Fernanda Amendola', Monica Martins Trovo' \\ ' Universidade de Guarulhos, Postgraduate Program in Nursing. Guarulhos, São Paulo, Brazil.
}

How to quote this article:

Abreu TFK, Amendola F, Trovo MM. Relational technologies as instruments of care in the Family Health Strategy. Rev Bras Enferm [Internet]. 2017;70(5):981-7. [Thematic Edition "Good practices and fundamentals of Nursing work in the construction of a democratic society"] DOI: http://dx.doi.org/10.1590/0034-7167-2016-0337

\author{
Submitted on: 07-11-2016 Approved on: 02-08-2017
}

\begin{abstract}
Objective: This article aims to identify the relational technologies used by Family Health Strategy nurses in their daily work when treating patients. Method: Descriptive and cross-sectional study with qualitative approach; conducted between May and July 2015, in three Basic Health Units of the Southern Region of the Municipality of São Paulo, with 19 nurses of the Family Health Strategy. Data were collected through a semi-structured interview, and the speeches were fully transcribed and analyzed according to the technique of content analysis. Results: From the speeches of the participants, three categories emerged, showing the unawareness of the concept, but the valorization of its use; which are the relational technologies used by the participating nurses (communication, listening, empathy and welcoming reception), as well as the report of barriers to the use of relational technologies. Final consideration: Although the nurses value the use of relational technologies, the participants denoted unawareness of the nomenclature and its associated concepts, suggesting superficiality in the understanding and use of these instruments in the context of care in the Family Health Strategy.
\end{abstract}

Descriptors: Interpersonal Relations; Communication; Nursing; Family Health Strategy; Welcoming Reception.

\section{RESUMO}

Objetivo: Identificar as tecnologias relacionais utilizadas por enfermeiros de Estratégia Saúde da Família em seu cotidiano de trabalho no atendimento aos usuários. Método: Estudo descritivo, transversal, com abordagem qualitativa; desenvolvido entre maio e julho de 2015, em três Unidades Básicas de Saúde da Região Sul do Município de São Paulo, com 19 enfermeiros da Estratégia Saúde da Família. Os dados foram coletados por meio de entrevista semiestruturada, e os discursos foram transcritos na íntegra, analisados segundo a técnica de análise de conteúdo. Resultados: Das falas dos participantes, surgiram três categorias, que evidenciam o desconhecimento do conceito, mas valorização do uso; quais são as tecnologias relacionais utilizadas pelos enfermeiros participantes (comunicação, escuta, empatia e acolhimento), além do relato de barreiras para a utilização de tecnologias relacionais. Considerações finais: Embora valorizem a utilização de tecnologias relacionais, os participantes denotaram desconhecer a nomenclatura e os conceitos associados, sugerindo superficialidade na compreensão e utilização dessas ferramentas no contexto de atendimento na Estratégia Saúde da Família.

Descritores: Relações Interpessoais; Comunicação; Enfermagem; Estratégia Saúde da Família; Acolhimento.

\section{RESUMEN}

Objetivo: Identificar las tecnologías relacionales utilizadas por enfermeros de la Estrategia Salud de la Familia en su cotidiano de trabajo en la atención a los usuarios. Método: Estudio descriptivo, transversal, con abordaje cualitativo. Fue desarrollado entre mayo y julio de 2015, en tres Unidades Básicas de Salud de la Región Sur del Municipio de São Paulo, con 19 enfermeros de la Estrategia Salud de la Familia. Los datos fueron recolectados por medio de una entrevista semiestructurada, y los discursos fueron transcritos en su totalidad y analizados según la técnica de análisis de contenido. Resultados: De las declaraciones de los participantes surgieron tres categorías, que son: el desconocimiento del concepto, pero la valorización del uso; cuales son las tecnologías relacionales utilizadas por los enfermeros participantes (comunicación, escucha, empatía y acogida); y el relato de barreras para la utilización de tecnologías relacionales. Consideraciones finales: Aunque valoren la utilización de tecnologías 
relacionales, los participantes demostraron desconocer la nomenclatura y los conceptos asociados, sugiriendo superficialidad en la comprensión y utilización de esas herramientas en el contexto de atención en la Estrategia Salud de la Familia.

Descriptores: Relaciones Interpersonales; Comunicación; Enfermería; Estrategia Salud de la Familia; Acogida.

\section{CORRESPONDING AUTHOR_Tatiana Fernandes Kerches de AbreuＥ-mail: tatianakerches@gmail.com}

\section{INTRODUCTION}

Regarding health, the use of interpersonal skills may be the positive differential in relations ${ }^{(1-2)}$. On the other hand, the lack of interpersonal skills and the result of inappropriate communicative attitudes of the professionals in their relations with the patients can negatively interfere with the quality of care offered $^{(3)}$. Interpersonal communication is the basis and the most important aspect of human relations ${ }^{(4)}$ and, as the foundation of interpersonal relations, it is a basic instrument for healthcare ${ }^{(5-6)}$.

The development of interpersonal competence is, above all, self-development ${ }^{(2)}$; that is, it depends on intrapersonal aspects. The organizations may define and direct the necessary and desirable knowledge, skills and actions of the contributors, however, individual effort for improvement is certainly essential ${ }^{(1)}$. The use of relational technologies by health professionals may favor the development of interpersonal competence $^{(7-8)}$.

Technology is comprehended as the intentional search for the production of goods and products that function as objects, not only material but symbolic, which carry usage values and satisfy needs. They can be classified as hard technologies (instrumental, norms, routines and organizational structures), light-hard technologies (structured knowledge, such as physiology, anatomy, psychology, medical and surgical procedures) and light technologies (related to the knowledge produced by the relations among the individuals) ${ }^{(8)}$.

Light technologies are present in the work relational space, materialize themselves in the individuals' actions and can be called relational technologies. They comprise the welcoming reception, integration, development of nurse-patient attachment, space for meetings and listening, respect and appreciation for autonomy, cooperation and co-responsibleness, use of communication skills for adequate verbal expression, good humor, empathy and ethical posture ${ }^{(7-8)}$.

Therefore, this research's object of study comprises relational technologies in care delivery, a phenomenon that was explored from the perspective of nurses from Family Health Strategy (FHS) teams. The nurse's perspective on relational technologies was selected as a source of research as nurses are the care managers, guiding the actions of the nursing auxiliary staff and community health agents in primary healthcare ${ }^{(9)}$.

The FHS is an instrument for reorienting the care model in primary healthcare, implemented through the establishment of multiprofessional teams in the primary health units (PHU), responsible for monitoring up to 4 thousand families in a defined geographical area. The teams are composed of at least one family doctor, one nurse, one nursing auxiliary or technician and six community health agents, and the teams operate with actions to promote health, prevention, recovery, rehabilitation of diseases and more frequent injuries, as well as to maintain the community's health ${ }^{(9)}$.

This model stands out for establishing relations of commitment and co-responsibility with the population, contributing to the expansion of primary healthcare in its political-institutional dimension, through the promotion of equity and integrality of care, favoring multidisciplinary work, emphasis on family and humanization in care development ${ }^{(10)}$.

Welcoming reception and development of interpersonal relationships are considered positive and differential elements of the FHS when compared with the traditional primary healthcare model ${ }^{(10-12)}$. However, in actuality, the work process is sometimes focused on the current illness and complaint, weakening the establishment of interpersonal relationships ${ }^{(11-15)}$, which may influence the patients' engagement with the actions directed at them ${ }^{(10,14)}$ and contribute to the fragmentation of care and distancing of nurses ${ }^{(13)}$.

Relationship problems among FHS team members may be factors that influence healthcare provided for the patient, a model which is based on multidisciplinary action and interaction $^{(9-10)}$. Such relational conflicts are evidenced by the national(16-17) and international(18-20) literature, involving lack of dialogue, respect and trust, as well as communication difficulties, which causes problems of self-esteem, discouragement and emotional exhaustion. This strongly affects not only the worker's health, but also the quality of the service provided.

The difficulty in facing this relational problem may influence the current context of nurses' healthcare services, centered on procedures, with no regard for the other's problems and with impoverished listening, losing its caregiving aspect. Thus, the professionals' unfriendly attitude may result from the accommodation of the organizational way of work, the result of an archaic healthcare model incorporated to their actions, which overvalues procedures and processes to the detriment of people $\mathrm{e}^{(7-8)}$.

Even with technological advances, the valorization of the interpersonal relationship has lost potency and effectiveness ${ }^{(20)}$; that is, the solutions to the needs of health service patients are sought in procedures, hard or light-hard technologies, neglecting qualified listening, respect, trust and dialogue, and the use of light technologies.

In order to improve the worker-patient relationship in the context of primary healthcare, in which there seems to be a great deal of familiarity with hard and light-hard technologies (standards, procedures, protocols), it is necessary that FHS nurses explore the possibilities of light technologies. In light of the above, this research aimed to identify the relational technologies used by FHS nurses in their daily work in the caregiving of the patients in the health system. 


\section{METHOD}

\section{Ethical aspects}

The research followed Resolution 466/12 of the National Health Council(21), which deals with research involving human beings. It was approved by the Research Ethics Committees (REC) of the Guarulhos University in April 2015, and validated by the CEP of the Municipal Health Department of the Municipality of São Paulo on April 15, 2015.

\section{Theoretical-methodological reference}

A descriptive study, with a qualitative approach, conducted in the city of São Paulo, in the periphery health sub-district, where low-income people live in communities, low-income households and subsidized housing estates. This is the subdistrict of operation of two of the researchers, who experience daily the problematics exposed, which motivated the study. This region has nine PUHs with $\mathrm{FHS}^{(22)}$. The three $\mathrm{PUH}$ s that attend to the largest number of people in this region (approximately 104,000 inhabitants) and, consequently, have a higher number of FHS teams, were selected as the research sites: PUH A (nine teams), PUH B (ten teams) and PUH C (seven teams), with 26 FHS teams. Although they are distinct, they have common characteristics regarding the peculiarities of the population attended to, the same administrative partner and, therefore, all the teams have the same philosophy and management procedures.

As each FHS team had a nurse, the research population comprised 26 of these professionals. The selection of nurses was because they are the care managers, who guide the actions of the nursing team and community health agents. The participants were selected in a non-random manner, for convenience, considering the criteria: being a nurse, belonging to the FHS team of one of the three selected units and having at least 12 months of work experience in the FHS.

Data collection was conducted between May and July 2015, with an individual approach to nurses in their work places, presentation of the research objectives and the invitation to participate. From the 20 nurses who met the inclusion criteria, 19 accepted to participate in the study and signed the Informed Consent Form, which was developed based on the precepts of Resolution 466/12 of the National Health Council(22).

Data were collected from a semistructured interview, with a script developed for the master's research, which contained in its heading the concept of hard, light-hard and light or relational technologies, considering that the nurse might not know the terminology. In this script, there were questions regarding sociodemographic data and three guiding questions, which concerned relational technologies in the FHS: 1) Which relational technologies do you use in your daily work? 2) In your point of view, in what way could relational technologies be used by nurses in the FHS? 3)What could favor the use of these relational technologies? And what could hinder it? Each interview was recorded in digital format and fully transcribed, respecting the colloquialism present in the speech.

The data were analyzed according to Content Analysis ${ }^{(23)}$. This strategy proposes a set of verbal communication analysis techniques, applied to the discourses, to obtain indicators that allow the description of the content of the interviewees' messages and it is composed of three stages: pre-analysis; exploration of the material and treatment of the results; and inference and interpretation.

In the pre-analysis, an extensive reading of all the material was conducted in order to fully comprehend the text, followed by critical-analytical reading to identify and highlight passages with significant connotations and similarities. These passages were then extracted from the text and reorganized into comparable units, according to the criterion of thematic approximation, followed by their exploration. In the second phase, coding operations were conducted with the previously extracted passages and then they were organized again by differentiation and regrouping, in order to group them into units that would allow the description of the specificities of their content. Then, the last stage was followed, with the categorization of previously coded elements of discourse, according to the emergent theme, and inferential and interpretative analysis of the categories.

To guide the critical analysis of the results, the theoretical frameworks of technology in work ${ }^{(8)}$ and also the interpersonal communication ${ }^{(4)}$ were used.

\section{RESULTS}

Out of the 19 participants in this study, 17 (89.5\%) were female and $2(10.5 \%)$ were male. The mean age of the nurses was $37 \pm 7$ years, the mean training time $11 \pm 7$ years and the mean time of work performance as a nurse in the FHS $6 \pm 4$ years. Regarding professional improvement, the $19(100 \%)$ interviewees had a specialization. Out of these, 15 (79\%) were specialized in Public Health or FHS.

Through the exploration and systematic analysis of the discourses it was possible to identify three categories: Unaware of the concept of relational technologies, but valuing its use; Identifying relational technologies used by nurses in the FHS: communication, listening, empathy and welcoming reception; and Reporting barriers to the use of relational technologies. These categories and the participants' discourses that illustrate them are described below.

\section{Not knowing the concept, but valuing its use}

In this category, it was evidenced, through the speeches, that nurses value the use of relational technologies, but are unaware of the nomenclature referred to and its associated concepts. Even so, they managed to mention them superficially, as the speeches illustrate:

... they use them, but they do not know what they are using, they don't have this notion of what is light, hard technology ... so ... they make use of them, they just can't identify what it is. The light one, mainly ... The welcoming reception! (E3)

Dialogue, it's ... how do you say when you ... it's not cooperation .... it's ... how am I going to explain it ... when you have to ... I don't know how to explain it. I don't remember now. The best then is the dialogue ... (E10)

Nowadays we have used technology a lot in the sense of the light one. In the last 4 years we have been using it. We have used it as an instrument. (E14) 
Each one sees much of their own work and does not see it as a whole. I believe this technology would help a lot, because we deal a lot with people, and it's not a job that you do individually. (E17)

Identifying relational technologies used by nurses in the FHS: communication, listening, empathy and welcoming reception

Although they showed unawareness of the terminology "relational technologies," nurses reported in their discourses to use them in their work routine attending to the population. The communication, listening, empathy and welcoming reception were mentioned, as exemplified by their speeches:

Nowadays, all of us are using it, but we know that there are nurses who do not have the profile to work in the Family Health Program (PSF) because they do not know how to use these technologies. Empathy, communication, listening, bonding ... (E1)

The welcoming reception! The welcoming reception encompasses a lot, when we ... Everything you do is a way to embrace them. The handling, the way I am here receiving you with your research is an welcoming reception, the way I treat the patient is an welcoming reception, anyway ... [...] You try ... for example, you are discussing a patient's problem, if you put yourself in the patient's shoes, it's already empathy. So it is already a way for you to use this kind of technology, to participate in the other person's problem. (E3)

... we give priority to the welcoming reception, priority to qualified listening of the patient, but we can't necessarily do everything that is needed ... (E5)

We will use the hard technologies also through equipment ... in the nursing consultations ... so we use them a lot. Weighing the children, performing the prenatal visit ... we use communication. (E7)

The major principle is communication. [...] Improve listening, sometimes we send a message, but the person who receives this message interprets otherwise. Then there is doubt, at that moment of doubt you were ready to resume there is already some misunderstanding, then you have to stop and restart from scratch so that the person can understand the information and reach a conclusion. (E19)

\section{Reporting barriers to the use of relational technologies}

In this category, it was indicated that the functional environment in which the nurse's work in the FHS occurs and the dynamics of the labor process in which it is inserted are unfavorable to the use of relational technologies, constituting barriers to their use. Thus, they indicate that the lack of physical space, the free demand of service and the bureaucratic processes hinder the use of relational technologies:

We have difficulties because of the physical space, [...] they knock at the door all the time, we are working and another one comes and knocks at the door. Or [...] other people arrive to discuss another case that is going on out there. This is one of the things that makes our job more difficult. (E2)
Doors knocking, sometimes you are with a patient or in a meeting and someone opens the door at once because this unit is open, which facilitates access for everyone so ... the patients enter and open the door anytime they want. (E7)

We attend to 40 people per period [morning or afternoon] when you are downstairs [reception room]. This is absurd. Patients are very demanding; they don't understand that there are rules here. So, everything that we try to do ends up being interrupted. (E9)

... we provide a service that ... it is not always that the service that we provide was scheduled; It is a service that has to do with free demand. It's ... in the FHS, we deal with different schedules, people with needs that have no time to happen and you have to give answers to these needs. I feel overwhelmed in this sense, with many demands and little time to invest in this planning issue, to have time to do everything, to give a resolution ... (E12)

I think what's in the way is bureaucracy. [...] ... if you get a more complicated family, like, I attend to people who use drugs, families with a much altered family process, then it will take more time. This family comes back about three times, but it is only worth a visit. And how do I justify that I spent all that time with a single family, as I should deal with many more ... as in one morning a nurse has to make 7 home visits and I spent an entire morning with a single family. So that's it, public health needs qualitative data rather than quantitative data. (E14)

\section{DISCUSSION}

It is noteworthy that the participants had a reasonable age and professional experience, and most of them had expertise in basic care, which causes uncanniness as to the unawareness of the nomenclature "light" or "relational technology." Although the terminology has been in the national literature for more than a decade $\mathrm{e}^{(7-8,20)}$, it seems that its use is not yet common among the nurses participating in this study, considering the mentioned difficulty of conceptualization, frequent interruptions of speech and forgetfulness concerning the terms.

From the speeches, it is possible to perceive that there is a superficiality of the understanding of light or relational technologies. And, in face of this superficiality, a reflection emerges regarding the real perception of the use of these technologies by the nurses as an instrument for the exercise of care.

However, in this context, it must be considered that hard and light-hard technologies are more easily identified due to their concreteness, while light technologies, due to their subtle nature, depend on the professional's directed attention. Hard and light-hard technologies are part of the everyday health work; however, they cannot overlay the light ones, as the light ones project a new focus on healthcare, with a resignification of the role of workers and patients, enabling the subjectivity of both agents to be expressed ${ }^{(7-8,20)}$.

There is a necessity to qualify health workers, in order for them to comprehend and use these technologies, so that the humanization of healthcare can actually be effected ${ }^{(8,20)}$. Thus, 
permanent education could favor the improvement of the knowledge required to use the technologies, since a better understanding of the concepts could facilitate their application by professionals, in addition to supporting the actions of nurses who have already adopted such instruments in their practices for a long time, although in an empirical or unconscious way ${ }^{(20)}$.

The nurses who participated in this research pointed communication, listening, empathy and welcoming reception as fundamental relational technologies in their daily work in primary care. The valorization of communication as a basic instrument of care in the context of primary care is consensual in the literature $\mathrm{e}^{(1-7,13,18-20,24-26)}$ regarding relational technologies.

The communication reported by the professionals refers to the verbal dimension of the communication process, known as conversation or dialogue, and it mainly involves words and information verbally exchanged between the nurse and the patient. It comprises the use of words expressed through speech and writing. Also, what is to be informed requires clarity and the use of communication strategies when interacting and trying to express oneself, to clarify a fact or validate the understanding of something. It is a form of privileged interaction by the nurse when exploring information or providing guidance ${ }^{(26-27)}$. In this type of communication, the use of familiar terms, frequent use of examples, repositioning and argumentative power are key points to be considered ${ }^{(4,26)}$.

However, it is worth to emphasize that non-verbal communication was poorly remembered by the participants, a concerning issue, since it is the non-verbal dimension that qualifies verbal interaction ${ }^{(4,26-27)}$. Thus, the inquiry regarding the valorization of the verbal dimension arises, due to the unfamiliarity with the nonverbal influence in the interaction. For it is a large and complex process, communication must also be known and valued in both dimensions ${ }^{(2-4,19,27)}$.

Based on the assumption that communication can favor the structuring of the relation between health professionals and patients, it is also important to emphasize that it is one of the fundamental aspects for the understanding of the welcoming reception ${ }^{(12-13,28-29)}$, which is the basis for FHS and important for relational technology. The welcoming reception of the patient searching for healthcare is expressed through the relationship between this individual and the professional that attends to them, listening and dialoguing, in an attempt to identify needs and devise individual strategies to address them ${ }^{(1,28-29)}$.

In spite of continuous scientific advances, in the current context of healthcare, many actions have lost their caregiving aspect, since the focus on the disease and diagnosis privileges the professional's action centered on procedures, with little interest in the patient and with impoverished listening ${ }^{(20)}$. Thus, it is necessary to recover the ability to listen, which is more than having preserved auditory acuity, it comprises listening with all senses and cognitive functions on alert, being attentive to subliminal and non-verbal words and messages ${ }^{(4,27)}$. It is associated with empathy, the ability to interpret non-verbal signals as tone of voice, gestures and facial expressions, trying to understand the feelings behind what is being said, enabling the inference of the patient's feelings and behaviors, as well as the manifestation of interest in addressing demands and in offering emotional support to the other person ${ }^{(27,29)}$.
Although interviewees have pointed four instruments (communication, listening, welcoming reception and empathy) as relational technologies that they use, they did not deepen the description of their applications in daily work, denoting a superficial exploration. Other relational technologies indicated by the literature ${ }^{(7-8,18,20,29)}$, such as attachment, valuing individuals' autonomy, cooperation and co-responsibility, were not mentioned by the participants, reinforcing the superficial connotation of their theoretical knowledge and ability in using those instruments.

The research participants point that the environment and the labor process constitute barriers to the use of relational technologies in attending to the population. In this sense, it is important to consider that the resolution in the primary healthcare network is connected not only to the professionals' instrumental resource and technical knowledge, but also to the welcoming reception action, to the interpersonal attachment with the patient, to the meaning in the professional/patient relation, which suggests the encounter of subjects with the purpose of acting upon the field of health ${ }^{(10,12-15)}$. Therefore, the welcoming reception action and the attachment developed between the patient and family with the nurse and their FHS team allows the patient's free access to the unit. Faced with the impossibility of planning this situation, there is an increase in the demand of work for nurses, which was reported in the participants' speeches.

There is a high daily influx of patients searching for the nurse in the unit, without prior scheduling. Thus, many demands of problems of the population of this area are solved without an official appointment every day, with the demand of the professional in their own service room. Even if the professional advises the patient to schedule a time to be attended to, there are situations that need to be resolved on the day and that relate to the team which the patient is assigned to.

The proximity between the patient and the FHS nurse is foreseen by this current primary healthcare model. However, the strong emotional pressure resulting from patients' unmet needs is a systematic cause of distress, stress and weariness for nurses ${ }^{(13,16)}$, and can influence their quality of life ${ }^{(30)}$. This intimate mode of interaction between nurse and patient is relatively recent, since the FHS has been implemented for around decade, and it is quite different from the model long present in the hospital institutions, where concrete limits are established for the access of the patient. The research participants had mean time of six years of performance in the FHS, corroborating the fact that they have been recently acting according to this new model of care.

Thus, it is befitting that the demands be adapted to a work process centralized in the light technologies and in the emotional support to the contributors, so that the living work ${ }^{(8)}$ can operate with maximum degree of autonomy.

In order to adjust this healthcare model that does not allow planning, in addition to the bureaucratization of influx and rules, it is also necessary to promote the individuals' autonomy, encouraging self-care practices. A work process centered on light and light-hard technologies may be the condition for the service to be a provider of care; that is, it is a question of establishing communicating levels between the various 
individuals present in the scene of healthcare services, patients and workers, the ones who care and are cared for, resignifying knowledge, attitudes, ways of relating to each other and practices of care $^{(7-8,20)}$.

To this end, it is important to change the conception of the nurse's role in primary healthcare, deconstructing the current model, focused on procedures and processes, and rebuilding a new one, based on care and co-responsibleness. In this new model, the construction of the relational space is primordial. More than physical space, it constitutes a temporal space in the work routine, in which there is the possibility of establishing direct communication between professionals and patients, which is sheltering, comfortable and respecting privacy ${ }^{(8)}$.

The lack of physical private space for patient care was one of the barriers indicated by nurses to use of relational technologies. At the interviews, it was observed that the interruptions were constant, usually with no plausible justification. No urgencies were observed or mentioned to justify the interruptions, and the doors were closed. Furthermore, no concrete action taken by the nurse to limit those interruptions was verified. In the speeches, the culpability of the patient and the circumstance were accentuated, as well as the nurse's abstainment from the co-responsibility. The nurses problematize the situation, but remain passive, without pursuing strategies to change the situation. This may denote a certain difficulty of the professional in assuming the role of protagonist as the manager of the caregiving process.

\section{Study limitations}

As a limitation of the study, the data were collected at different moments, in three different locations. Although the collections had the same organizational philosophy and similar work process design, they had different characteristics concerning territory and population served.

\section{Contributions to nursing}

The data found are extremely relevant. This is because, in addition to indicating fragilities in the nurses' performance in the context of basic care according to the FHS model, the data reveal relational technologies that can be incorporated into the professional's care routine and the need for educational intervention in favor of improving relational skills in medium term aiming to change this scenario.

\section{FINAL CONSIDERATION}

In this research, considering the interviewed nurses' unawareness of the concept and superficiality of the explored relational technologies, it is possible to infer the fragility of the understanding and use of these instruments for the primary healthcare service.

With the discourse analysis, it was possible to show that nurses value the use of relational technologies, but they are unaware of their nomenclature and associated concepts. They emphasized communication, empathy, listening and welcoming reception as fundamental relational instruments and pointed the functional environment and the work process as barriers to the use of relational technologies.

Further studies on the subject are needed to explore with greater depth the possibilities of using relational technologies in the context of nurse's care and management work in the FHS.

\section{REFERENCES}

1. Rocha BS, Munari DB. Avaliação da competência interpessoal de enfermeiros coordenadores de equipe na saúde da família. Rev Enferm Atenção Saúde [Internet]. 2013[cited 2017 Jan 20];2(3). Available from: http://seer.uftm.edu.br/revistaeletronica/index. php/enfer/article/view/430/434

2. Braga EM, Silva MJP. Competent communication: a view of nurse experts in communication. Acta Paul Enferm[Internet]. 2007 [cited 2016 May 11];2012;20(4):1-8. Available from: http://dx.doi.org/10.1590/S0103-21002007000400004

3. Araújo MMT, Silva MJP, Puggina ACG. A comunicação não verbal enquanto fator iatrogênico. Ver Esc Enferm USP [Internet]. 2007 [cited 2016 May 05];41(3):419-25. Available from: http://www.scielo.br/pdf/reeusp/v41n3/11

4. Silva MJP. Comunicação tem remédio: a comunicação nas relações interpessoais em saúde. São Paulo: Edições Loyola; 2011. p.21-8

5. Pontes AC, Leitão IMTA, Ramos IC. Comunicação terapêutica em Enfermagem: instrumento essencial do cuidado. Rev Bras Enferm [Internet]. 2008[cited 2016 May 05];61(3):312-8. Available from: http://dx.doi.org/10.1590/S0034-71672008000300006

6. Morais GSN, Costa SFG, Fontes WD, Carneiro AD. Comunicação como instrumento básico no cuidar humanizado em enfermagem ao paciente hospitalizado. Acta Paul Enferm[Internet]. 2009 [cited 2016 May 05];22(3):323-7.Available from: http://www. scielo.br/pdf/ape/v22n3/a14v22n3

7. Martins JJ, Albuquerque GL. A utilização de tecnologias relacionais como estratégia para humanização do processo de trabalho em saúde. Cienc Cuid Saúde[Internet]. 2007 [cited 2015 Nov 30];6(3):351-6. Available from: http://dx.doi.org/10.4025/cienccuidsaude. v6i3.4068

8. Merhy EE. Saúde: a cartografia do trabalho vivo. São Paulo: Hucitec; 2007. p.94-112.

9. Brasil. Ministério da Saúde. Secretaria de Atenção à Saúde. Departamento de Atenção Básica. Política Nacional de Atenção Básica. Brasília: Ministério da Saúde, 2012. 114p

10. Arantes LJ, Shimizu HE, Merchan-Hamann E. Contribuições e desafios da Estratégia Saúde da Família na Atenção Primária à Saúde no Brasil: revisão de literatura. Ciênc Saúde Colet [Internet]. 2016 [cited 2016 May 05];21(5):1499-509. Available from: http:// www.scielo.br/pdf/csc/v21n5/en 1413-8123-csc-21-05-1499.pdf 
11. Ogata MN, Machado MLT, Catoia EA. Saúde da família como estratégia para mudança do modelo de atenção: representações sociais dos usuários. Rev Eletr Enferm [Internet]. 2009 [cited 2016 May 05];11(4):820-9. Available from: https://www.fen.ufg.br/ fen_revista/v11/n4/pdf/v11n4a07.pdf

12. Sena ALC, Ferreira LN, Oliveira RS, Kozmhinsky VMR. Acolhimento e satisfação do usuário na Estratégia de Saúde da Família: uma experiência de êxito. Rev APS[Internet]. 2015 [cited 2016 May 05];18(2):134-40. Available from: https://aps.ufjf.emnuvens. com.br/aps/article/view/2326/871

13. Costa PCP, Garcia APRF, Toledo VP. Acolhimento e cuidado de enfermagem: um estudo fenomenológico. Texto Contexto Enferm [Internet]. 2016[cited 2016 May 05];25(1):e4550015. Available from: http://www.scielo.br/pdf/tce/v25n1/pt_0104-0707-tce-25-01-4550015.pdf

14. Silva TF, Romano VF. Sobre acolhimento: discurso e prática em Unidades Básicas de Saúde do município do Rio de Janeiro. Saúde Debate [Internet]. 2015 [cited 2016 May 05];39(105):363-74. Available from: http://www.scielo.br/pdf/sdeb/ v39n105/0103-1104-sdeb-39-105-00363.pdf

15. Lopes AS, Vilar RLA, Melo RHV, França RCS. O acolhimento na atenção básica em saúde: relações de reciprocidade entre trabalhadores e usuários. Saúde Debate [Internet]. 2015 [cited 2015 Nov 30];39 (104):114-23. Available from: http://www.scielo.br/ pdf/sdeb/v39n104/0103-1104-sdeb-39-104-00114.pdf

16. Trindade LL, Lautert L, Beck CLC, Amestoy SC, Pires DEP. Stress and Burnout Syndrome among workers of the Family Health Team. Acta Paul Enferm[Internet]. 2010[cited 2016 Jul 11];23(5):684-9. Available from: http://dx.doi.org/10.1590/S0103-21002010000500016

17. Fernandes HN, Thfehrn MB, Porto AR, Amestoy SC, Jacondino MB, Soares MR. Relacionamento interpessoal no trabalho da equipe multiprofissional de uma unidade de saúde da família. J Res Fundam Care[Internet]. 2015 [cited 2016 May 05]. Available from: http://www.seer.unirio.br/index.php/cuidadofundamental/article/view/3361/pdf_1429

18. Saya FA, Szafran O, Robertson S, Bell NR, Williams B. Nursing perspectives on factors influencing interdisciplinary teamwork in the Canadian primary care center. J Clin Nurs [Internet]. 2014 [cited 2016 Nov 06];23:2968-79. Available from: https://www.researchgate. net/publication/259983402_Nursing_perspectives_on_factors_influencing_interdisciplinary_teamwork_in_the_Canadian_primary_ care_setting

19. Yuguero O, Marsal JR, Esquerda M, Vivanco L, Soler-Gonzalez. Association between low empathy and high burnout among primary care physicians and nurses in Lleida, Spain. Eur J General Practice [Internet]. 2016 [cited 2016 Nov 06]. Available from: http://www.tandfonline.com/doi/full/10.1080/13814788.2016.1233173

20. Merhy EE, Feuerwerker LCM. Novo olhar sobre as tecnologias de saúde: uma necessidade contemporânea. In Mandarino ACS, Gomberg E (org). Leituras de novas tecnologias e saúde. Bahia: UFS; 2009; p. 29-56.

21. Brasil. Conselho Nacional de Saúde. Resolução n. 466, de 12 de dezembro de 2012[Internet]. Brasília. 2012[cited 2014 Nov 30]. Available from: http://www.conselho.saude.gov.br/web_comissoes/conep/index.html

22. São Paulo. Secretaria Municipal de Saúde. Estratégia Saúde da Família - ESF[Internet]. São Paulo. [cited 2014 Apr 30]. Available from: http://www.prefeitura.sp.gov.br/cidade/secretarias/saude/atencao_basica/esf/index.php?p=17783

23. Bardin L. Análise de Conteúdo. Lisboa: Edições 70; 2011. p.123-35

24. Aquino OS, Melo RP, Lopes MVO, Pinheiro AK. Análise do conceito de tecnologia na enfermagem segundo o método evolucionário. Acta Paul Enferm[Internet]. 2010 [cited 2016 May 05];23(5):690-96. Available from: http://www.scielo.br/pdf/ape/ v23n5/en_17.pdf

25. Kantorski LP, Jardim VMR, Pereira DB, Coimbra VCC, Oliveira MM. A integralidade no cotidiano de trabalho na Estratégia Saúde da Família. Rev Gaúcha Enferm[Internet]. 2009 [cited 2016 May 05];30(4):594-601. Available from: http://www.scielo.br/pdf/ rgenf/v30n4/a03v30n4

26. Little $\mathrm{P}$, White $\mathrm{P}$, Kelly J, Everitt $\mathrm{H}$, Gashi S, Bikker A, et al. Verbal and non-verbal behaviour and patient perception of communication in primary care. Br J Gen Practice [Internet]. 2015 [cited 2016 May 05];65(635):e357-e365. Available from: https://www.ncbi.nlm. nih.gov/pmc/articles/PMC4439825/

27. Araújo MMT, Silva MJP. Estratégias de comunicação utilizadas por profissionais de saúde na atenção a pacientes sob cuidados paliativos. Rev Esc Enferm USP [Internet]. 2012[cited 2017 Jan 20];46(3):626-32. Available from: http://dx.doi.org/10.1590/S0080-62342012000300014

28. Moura EL, Santos RS, Rocha SS. Evidências sobre o acolhimento e vínculos de enfermeiros da Estratégia Saúde da Família junto aos adolescentes. Rev Saúde Foco[Internet]. 2015[cited 2017 Jan 20];2(2). Available from: http://www4.fsanet.com.br/revista/ index.php/saudeemfoco/article/view/553/0

29. Coelho MO, Jorge MSB. Tecnologia das relações como dispositivo para o atendimento humanizado na atenção básica à saúde, na perspectiva do acesso, do acolhimento e do vínculo. Cienc Saúde Colet[Internet]. 2009[cited 2016 May 05];14(1):1523-31. Available from: http://www.redalyc.org/pdf/630/63011684023.pdf

30. Souza DJ, Ferreira MBG, Felix MMS, Contim D, Simões ALS. Caracterização do contexto de trabalho e qualidade de vida dos profissionais da Estratégia Saúde da Familia. Cogitare Enferm [Internet]. 2015. [cited 2017 Jan 20];30(3):565-72. Available from: http://dx.doi.org/10.5380/ce.v20i3.41124 